\title{
Phytochemical Analysis, Antioxidant and Antiarthritic Activity of Aqueous Extracts of Gmelina arborea Flowers
}

\author{
Ayushi Rajput, Sourabh Jain* and Karunakar Shukla \\ College of Pharmacy, Dr. A. P. J. Abdul Kalam University, Indore, MP, India \\ *Corresponding Author: Sourabh Jain, College of Pharmacy, Dr. A. P. J. Abdul Kalam \\ University, Indore, MP, India.
}

Received: September 02, 2020

Published: September 28, 2020

(C) All rights are reserved by Sourabh Jain., et al.

\begin{abstract}
The plant Gmelina arborea (G. arborea) has been traditionally used in India for several medicinal purposes like anthelmintic, diuretic, antibacterial, antioxidant and antidiabetic. The aim of the present study was to evaluate qualitative phytochemical analysis, antioxidant and antiarthritic activities of aqueous extracts of G. arborea flowers. Qualitative analysis of various phytochemical constituents was determined by the well-known test protocol available in the literature. The in vitro antioxidant activity was assessed against 2, 2-diphenyl-1-picrylhydrazyl (DPPH) and superoxide scavenging assay using standard protocols. The in vitro antiarthritic potential of extracts was evaluated in terms of its inhibition of protein denaturation and membrane stabilization method. Freund's adjuvant arthritis model in Wistar rats was used to study the in vivo antiarthritic activity. Phytochemical analysis revealed the presence of alkaloids, glycosides, phenols, flavonoids, tannins. The inhibitory concentration 50\% values are $85.43 \mathrm{and} 107.59 \mu \mathrm{g} / \mathrm{ml}$ for DPPH radical scavenging assay and superoxide scavenging assay, respectively. The plant extracts exhibited dose dependent inhibition of protein denaturation and also protected the RBC cells by stabilizing the membranes. G. arborea flowers extracts (100 and $200 \mathrm{mg}$ / $\mathrm{kg}$ ) was given orally to arthritic rats induced with complete freund's adjuvant and changes in paw diameter, joint diameter, arthritic score and body weight were determined. Indomethacin was taken as standard. Rats treated with extracts displayed marked reduction in paw diameter, joint diameter and arthritic score along with substantial enhancement in body weight. The antiarthritic effects of these plant extracts may attribute either due to its inhibition of protein denaturation or stabilizing the membranes from the free radical attack which are generated due to the immunological and inflammatory reactions observed in most of the arthritic conditions.
\end{abstract}

Keywords: Gmelina arborea; Phytochemical Analysis; Antioxidant; Antiarthritic Activity

\section{Introduction}

Reactive oxygen species (ROS) are highly reactive molecules which may be both important mediators of some physiological functions and also potential prooxidants. Imbalance between ROS generation and antioxidant capacity induces a condition known as oxidative stress which may play a major role in the initiation and progression of numerous pathologies including cardiovascular dysfunction associated with vascular disease, hyperlipidemia, diabetes mellitus, hypertension and ischemia/reperfusion injury. The potential damage caused by an excess of ROS is controlled by a series of antioxidant defense mechanisms and among them, a key protective role is played by the antioxidant enzymes glutathione (GSH) peroxidase, superoxide dismutase (SOD) and GSH reductase [1]. Rheumatoid Arthritis (RA) is an autoimmune disease that results in a chronic, systemic inflammatory disorder that causes pain, swelling, stiffness and loss of function in joints [2]. It occurs more frequently in women than in men and its prevalence depends upon age. In humans, RA is the most common inflammatory joint disease where skeletal complications start with focal erosion of cartilage initially followed by marginal and sub-chondral bone loss. Extended joint destruction with ankylosis and generalized bone loss are characteristic for late complications [3]. The steroidal and 
non-steroidal anti-inflammatory drugs are used in the treatment of the disease, but they offer only temporary relief and produce severe side effects including gastrointestinal bleeding and cardiovascular toxicity. Consequently, there is a need to develop new long acting anti-inflammatory agents with minimum side effects. Herbal medicine is a form of alternative treatment for several ailments and plant derived drugs are gaining popularity both in developing and developed countries due to their natural origin and less side effects in the last few years. The World Health Organization (WHO) has listed 21,000 plants which are used for medicinal purposes around the world and India is known as the "Emporium of Medicinal plants" due to availability of several thousands of medicinal plants in the different bioclimatic zones. Plant derived secondary metabolites in the plant extracts are the important source of drugs with desired pharmacological activity. Although herbal drugs are effective in treatment of various ailments, very often these drugs are unscientifically exploited and/or improperly used. Therefore, a detailed pharmacological evaluation and documentation of plants used in local health tradition is needed. G. arborea (Verbenaceae), popularly known as Gambhari, is an important medicinal plant in the Indian Ayurvedic system of medicine. The drupes, leaves, flowers, roots and bark are used in traditional medicine. The plant is used in snake-bite and scorpion sting. The juice of tender leaves added to cow's milk is used in gonorrhea. Leaves ground into paste with water are applied to the forehead for headache in fevers [4]. The plant is anthelmintic and is useful in treatment of piles, abdominal pains, burning sensations, fever [5] and diabetes [6]. A large number of phytoconstituents have been identified in different parts of $G$. arborea including flavonoids, steroids, alkaloids, glycosides, and lignans. Luteolin [7], indole alkaloids [8] and iridoid glycosides [9] have been isolated from the leaves. The occurrence of hentriacontanol [10] and lignans like arboreol, isoarboreol, methyl arboreol, arborone, gmelanone, gummadiol, gmelanone, and 7-oxodihydrogmelinol [11-13] in the heartwood has also been reported. Crude extracts of $G$. arborea have also been investigated for different pharmacological activities. The extract form of leaves is reported to have wound-healing properties [14]. The aqueous methanol extract (ME) of the bark showed an antidiarrheal activity in castor oil-induced diarrhea in mice [15]. The aqueous extract of the bark and fruit of $G$. arborea have been studied for a hepatoprotectant and antioxidant activity using liver slice culture [16]. The present study was designed to evaluate the antioxidant and antiarthritic activity of extract supporting its traditional use in arthritis.

\section{Materials and Methods}

Plant material

Flowers of $G$. arborea (Verbenaceae) were purchased from the local market of Indore Madhya Pradesh, India. The taxonomical recognition (Plant Authentication No. 178/Bot-DAVV/2018) was done from Department of Botany, DAVV University, Indore, Madhya Pradesh.

\section{Chemical reagents}

All the chemicals used in this study were obtained from $\mathrm{Hi}$ Media Laboratories Pvt. Ltd. (Mumbai, India), Sigma-Aldrich Chemical Co. (Milwaukee, WI, USA), SD Fine-Chem. Ltd. (Mumbai, India) and SRL Pvt. Ltd. (Mumbai, India). Clonidine (Unichem, Ltd.); Chlorpheniramine maleate (Alkem, Mumbai), All the chemicals used in this study were of analytical grade.

\section{Preparation of extract}

The collected yellow colored flowers (100 gm) were extracted (decoction) with water $(500 \mathrm{ml})$ at a temperature not exceeding $110^{\circ} \mathrm{C}$ for $2 \mathrm{hrs}$. The extract was allowed to cool, filtered and lyophilized. The yield of obtained dried extract was $9 \% \mathrm{w} / \mathrm{w}$.

\section{Qualitative phytochemical analysis of plant extract}

The G. arborea extracts obtained was subjected to the preliminary phytochemical analysis $[17,18]$. The extract was screened to identify the presence or absence of various active principles like phenolic compounds, carbohydrates, flavonoids, glycosides, saponins, alkaloids, fats or fixed oils, protein and amino acid and tannins.

\section{In vitro antioxidant activity}

2,2-diphenyl-1-picrylhydrazyl (DPPH) radical scavenging assay

The DPPH assay of extract was determined using ultraviolet spectrophotometer $[19,20]$, which involved the preparation of standard, test, and control.

\section{Preparation of standard rutin solutions}

Different solutions (20 - $100 \mu \mathrm{g} / \mathrm{ml})$ of the rutin were prepared in methanol. $1.5 \mathrm{ml}$ of each solution of rutin was mixed with $1.5 \mathrm{ml}$ of $200 \mu \mathrm{M}$ DPPH solution and fecundated for 30 minutes at room temperature in dark. Absorbance of each solution was taken after 30 minutes against methanol (as blank) at $517 \mathrm{~nm}$. 


\section{Preparation of test solutions}

Different solutions of the extract were prepared in methanol to give concentrations in the range of $20-100 \mu \mathrm{g} / \mathrm{ml} .1 .5 \mathrm{ml}$ of each extract solution was blended with $200 \mu \mathrm{M}$ DPPH solution and incubated for 30 minutes at room temperature. Optical density was measured after 30 minutes against methanol (as blank) at $517 \mathrm{~nm}$.

\section{Preparation of control solution}

For control, $1.5 \mathrm{ml}$ of methanol was mixed with $200 \mu \mathrm{M}$ DPPH solution and incubated for 30 minutes at room temperature in dark. Absorbance of the control was taken after 30 minutes against methanol (as blank) at $517 \mathrm{~nm}$.

\section{Superoxide scavenging assay}

Different concentrations (20 - $100 \mu \mathrm{g} / \mathrm{ml})$ of rutin and test sample were prepared. To the reaction mixture carrying $0.1 \mathrm{ml}$ of NBT, $0.3 \mathrm{ml}$ of extract and $1 \mathrm{ml}$ of alkaline DMSO was added to give a final volume of $1.4 \mathrm{ml}$ and the absorbance was fixed at $560 \mathrm{~nm}$. Plain DMSO used as blank and reaction mixture without extract (water in place of extract) used as control. Depreciate absorbance of the reaction mixture designated the increasing of superoxide anion scavenging activity. 50\% inhibition of extract was determined by plotting a graph between absorbance and concentration [21].

\section{In vitro anti-arthritic activity}

\section{Protein denaturation inhibition study}

Protein denaturation was executed as mentioned below. Different concentrations ranging from $100-500 \mu \mathrm{g} / \mathrm{ml}$ for both test sample and standard acetylsalicylic was composite with egg albumin solution ( $1 \mathrm{mM}, 1 \mathrm{ml})$ and incubated at $27^{\circ} \mathrm{C}$ for around $15 \mathrm{~min}$ utes. Further reaction mixture was maintained at $70^{\circ} \mathrm{C}$ in a water bath for 10 minutes for denaturation. A sample was allowed to cool down and was spectrophotometrically at $660 \mathrm{~nm}$. Percentage inhibition of denaturation was calculated from control without sample and standard. All the experiment was performed in triplicate [22].

\section{Membrane stabilization study}

Extract sample subsisted of stock erythrocyte (RBCs) suspension $0.03 \mathrm{ml}$ infused with hypotonic solution ( $5 \mathrm{ml})(154 \mathrm{mM} \mathrm{NaCl}$ in $10 \mathrm{mM}$ Sodium Phosphate Buffer at $\mathrm{pH}$ 7.4) enclosing test sample ranging from concentration $100-500 \mu \mathrm{g} / \mathrm{ml}$. The blank was performed. The standard drug acetylsalicylic was treated similarly. The experiment was done in triplicate. The mixtures were allowed for incubation at room temperature for around 10 minutes, fol- lowed by centrifugation (10 minutes at $3000 \mathrm{rpm}$ ). Absorbance of the supernatant was uniformed spectrophotometrically at $540 \mathrm{~nm}$. The percentage inhibition of haemolysis was computed by following equation [23].

\section{In vivo anti-arthritic activity}

\section{Complete Freund's adjuvant (CFA) induced arthritis}

Complete Freund's adjuvant (CFA) model was performed to evaluate the antiarthritic activity. Albino Wistar male rats of weight $200 \pm 25$ gm were used for the experiment. Route of administration was P.O. Animals were placed in different cages in group under controlled conditions of temperature $\left(22 \pm 2^{\circ} \mathrm{C}\right)$. Golden feed diet and water were administered to all the animals regularly. The dose adopted $100 \mathrm{mg} / \mathrm{kg}$ and $200 \mathrm{mg} / \mathrm{kg}$ b.w. Paw diameter, joint diameter, arthritic score, body weight was used as a parameter for the activity. Institutional Animal Ethics Committee (IAEC) approval was taken (IAEC: SBRL/IAEC/PN-18040) for performing the experiments. Animals were divided into five groups. Vehicle/ drug was administered orally and after 30 minutes of waiting period, $0.1 \mathrm{ml}$ of CFA $(0.05 \%$ Mycobacterium butyricum in mineral oil) was injected into left hind paw (subplantar surface) with a 26 gauge needle. Paw diameter, joint diameter, arthritic score, body weight measurements was carried out on days $3^{\text {rd }}, 7^{\text {th }}, 14^{\text {th }}$ and $21^{\text {st }}$. All were compared to standard Indomethacin and evaluated [24].

\section{Animal grouping}

- Group I: Vehicle (Normal Saline, $10 \mathrm{ml} / \mathrm{kg}$ )

- $\quad$ Group II: CFA + Normal saline $(10 \mathrm{ml} / \mathrm{kg})$

- $\quad$ Group III: CFA + Std (Indomethacin $3 \mathrm{mg} / \mathrm{kg}$ )

- Group IV: CFA + G. arborea extract treated (100 mg/kg)

- Group V: CFA + G. arborea extract treated (200 mg/kg).

\section{Statistical analysis}

Statistics were asserted as mean \pm Standard Error Mean (SEM). Differences were considered significant at ${ }^{* * *} \mathrm{P}<0.001$, or ${ }^{* *} \mathrm{P}<$ 0.01 or $* \mathrm{P}<0.05$ when compared test group vs control (-ve) group. For numerical results, one-way analysis of variance (ANOVA) (compare all vs. control) was performed using Graph Pad InStat Version 3 (Graph Pad Software).

\section{Results and Discussions}

The results of qualitative phytochemical analysis of the crude powder of flower of G. arborea are shown in table 1. Aqueous ex- 
tracts of flower sample of $G$. arborea showed the presence of, alkaloids, flavonoids, sterols, volatile oil, tannins and glycosides. In vitro anti-oxidant activity of the aqueous extract of $G$. arborea flowers was determined by evaluating the DPPH and superoxide scavenging assay. The experiment was done in triplicate for both the sample The $\mathrm{IC}_{50}$ values are $85.43 \mu \mathrm{g} / \mathrm{ml}$ and $107.59 \mu \mathrm{g} / \mathrm{ml}$ for DPPH radical scavenging and superoxide scavenging assay respectively, $\mathrm{Ru}-$ tin was used as reference standard. The G. arborea aqueous extract has significant antioxidant activity against DPPH scavenging assay and superoxide scavenging assay. Plant exhibits the antioxidant activity through the scavenging of free radicals (Table 2 and 3 ). The G. arborea aqueous extract was found to possess membrane stabilizing property which is one of the preliminary steps involved in the screening of anti-inflammatory property. Membrane of RBC structurally resembles the lysosomal membrane; the effect of any substance on stabilization of RBC membrane may be extrapolated to the stabilization of lysosomal membrane (Table 4). Anti-arthritic effect of $G$. arborea was studied significantly by using in-vitro inhibition of protein denaturation and it can be concluded that G. arborea extract can serve as an anti-arthritic agent as tabulated in table
5. Complete Freund's adjuvant (CFA) induced arthritis protocol was adopted. Vehicle/drug treatment was continued for the duration of 20 more days. Arthritic parameters like arthritic score, joint diameter and paw diameter were recorded. Arthritic parameters show that $G$. arborea possesses significant anti-arthritis activity. The aqueous extract of $G$. arborea possesses anti-inflammatory and anti-arthritic activity observed in parameters like paw edema, arthritic index and joint diameter. The presence of various phytoconstituents in G. arborea plant passes antiarthritic activity (Table 6-9).

\begin{tabular}{|l|c|c|}
\hline S. No. & Secondary Metabolites & Result \\
\hline 1 & Glycoside & Present \\
\hline 2 & Alkaloid & Present \\
\hline 3 & Sterols & Present \\
\hline 4 & Volatile oil & Present \\
\hline 5 & Tannins & Present \\
\hline 6 & Triterpenoids & Present \\
\hline
\end{tabular}

Table 1: Phytochemical evaluation of G. arborea flowers.

\begin{tabular}{|c|c|c|c|c|c|c|c|c|}
\hline \multirow[b]{2}{*}{ S. No } & \multirow{2}{*}{$\begin{array}{c}\text { Conc. } \\
(\mu \mathrm{g} / \mathrm{ml})\end{array}$} & \multicolumn{3}{|c|}{ Absorbance at $517 \mathrm{~nm}$} & \multicolumn{2}{|c|}{ Inhibition (\%) } & \multicolumn{2}{|c|}{$\mathbf{I C}_{50}(\mu \mathrm{g} / \mathrm{ml})$} \\
\hline & & Extract & Control & $\begin{array}{l}\text { Stan- } \\
\text { dard }\end{array}$ & Standard & Extract & $\begin{array}{l}\text { Stan- } \\
\text { dard }\end{array}$ & Extract \\
\hline 1 & 20 & 0.383 & 0.562 & 0.304 & $52.86 \pm 0.089$ & $31.42 \pm 0.399$ & 10.10 & 85.43 \\
\hline 2 & 40 & 0.332 & & 0.265 & $55.50 \pm 0.358$ & $36.42 \pm 0.224$ & & \\
\hline 3 & 60 & 0.287 & & 0.233 & $58.30 \pm 0.016$ & $40.97 \pm 0.145$ & & \\
\hline 4 & 80 & 0.254 & & 0.209 & $61.68 \pm 0.092$ & $45.81 \pm 0.083$ & & \\
\hline 5 & 100 & 0.222 & & 0.174 & $68.57 \pm 0.342$ & $56.53 \pm 0.347$ & & \\
\hline
\end{tabular}

Table 2: DPPH radical scavenging assay.

\begin{tabular}{|c|c|c|c|c|c|c|}
\hline \multirow{2}{*}{ S. No } & \multirow{2}{*}{$\begin{array}{c}\text { Conc. } \\
(\mu \mathrm{g} / \mathrm{ml})\end{array}$} & \multirow{2}{*}{$\begin{array}{l}\text { Absorbance } \\
\text { of Standard }\end{array}$} & \multicolumn{2}{|c|}{ Inhibition (\%) } & \multicolumn{2}{|c|}{$\mathrm{IC}_{50}(\mu \mathrm{g} / \mathrm{ml})$} \\
\hline & & & Standard & Extract & Standard & Extract \\
\hline 1 & 20 & 0.364 & $51.95 \pm 0.026$ & $25.61 \pm 0.377$ & \multirow[t]{5}{*}{11.18} & \multirow[t]{5}{*}{107.59} \\
\hline 2 & 40 & 0.339 & $57.30 \pm 0.226$ & $34.05 \pm 0.038$ & & \\
\hline 3 & 60 & 0.304 & $66.77 \pm 0.234$ & $38.06 \pm 0.029$ & & \\
\hline 4 & 80 & 0.263 & $72.42 \pm 0.261$ & $42.28 \pm 0.290$ & & \\
\hline 5 & 100 & 0.246 & $74.07 \pm 0.062$ & $47.73 \pm 0.186$ & & \\
\hline
\end{tabular}

Table 3: Superoxide scavenging assay. 


\begin{tabular}{|c|c|c|c|c|c|}
\hline \multirow{2}{*}{ S. No } & \multirow{2}{*}{ Conc. $(\boldsymbol{\mu g} / \mathbf{m l})$} & \multicolumn{2}{|c|}{ \% Inhibition } & \multicolumn{2}{c|}{ Absorbance at 540 nm } \\
\cline { 3 - 6 } & & Standard & Extract & Standard & Extract \\
\hline 1 & 100 & $37.93 \pm 0.247$ & $8.67 \pm 0.276$ & 0.204 & 0.278 \\
\hline 2 & 200 & $42.97 \pm 0.310$ & $12.40 \pm 0.310$ & 0.191 & 0.243 \\
\hline 3 & 300 & $47.14 \pm 0.117$ & $16.95 \pm 0.276$ & 0.179 & 0.223 \\
\hline 4 & 400 & $51.48 \pm 0.117$ & $20.76 \pm 0.193$ & 0.155 & 0.202 \\
\hline 5 & 500 & $57.23 \pm 0.089$ & $22.90 \pm 0.234$ & 0.138 & 0.192 \\
\hline
\end{tabular}

Table 4: Membrane stabilization activity of $G$. arborea extracts.

\begin{tabular}{|c|c|c|c|c|c|}
\hline \multirow{2}{*}{ S. No } & \multirow{2}{*}{ Conc. $(\boldsymbol{\mu g} / \mathbf{m l})$} & \multicolumn{2}{|c|}{ \% Inhibition } & \multicolumn{2}{c|}{ Absorbance at $660 \mathbf{~ n m}$} \\
\cline { 3 - 6 } & & Standard & Standard & Standard & Extract \\
\hline 1 & 100 & $67.73 \pm 0.448$ & $39.62 \pm 0.448$ & 0.179 & 0.339 \\
\hline 2 & 200 & $73.49 \pm 0.356$ & $44.25 \pm 0.625$ & 0.147 & 0.313 \\
\hline 3 & 300 & $79.89 \pm 0.178$ & $47.98 \pm 0.448$ & 0.112 & 0.292 \\
\hline 4 & 400 & $82.80 \pm 0.205$ & $51.66 \pm 0.719$ & 0.098 & 0.271 \\
\hline 5 & 500 & $85.23 \pm 0.178$ & $55.93 \pm 0.544$ & 0.083 & 0.247 \\
\hline
\end{tabular}

Table 5: Effect of G. arborea extracts on inhibition of protein denaturation.

\begin{tabular}{|l|c|c|c|c|c|}
\hline Groups & 0 day & 3 day & 7day & 14 day & 21 day \\
\hline G.1 (Vehicle) & $3.44 \pm 0.109$ & $3.56 \pm 0.113$ & $3.50 \pm 0.104$ & $3.52 \pm 0.131$ & $3.52 \pm 0.101$ \\
\hline G.2 (Positive control) & $3.58 \pm 0.164$ & $5.01 \pm 0.164$ & $5.23 \pm 0134$ & $5.89 \pm 0.150$ & 6.060 .123 \\
\hline G.3 (Standard) & $3.50 \pm 0.118$ & $4.08 \pm 0.089$ & $4.64 \pm 0.105$ & $4.89 \pm 0.120$ & $4.17 \pm 0.188$ \\
\hline G.4 (Extract-100 mg/kg) & $3.51 \pm 0.064$ & $4.74 \pm 0.125$ & $5.06 \pm 0.086$ & $5.46 \pm 0.063$ & $4.89 \pm 0.155$ \\
\hline G.5 (Extract-200 mg/kg) & $3.54 \pm 0.097$ & $4.42 \pm 0.108$ & $4.91 \pm 0.093$ & $5.17 \pm 0.136$ & $4.43 \pm 0.162$ \\
\hline
\end{tabular}

Table 6: Anti-arthritic activity of G. arborea on rat paw diameter (in $\mathrm{mm}$ ).

\begin{tabular}{|l|c|c|c|c|c|}
\hline Groups & 0 day & 3 day & 7 day & 14 day & 21 day \\
\hline G.1(Vehicle) & $6.10 \pm 0.605$ & $6.1 \pm 40.593$ & $6.10 \pm 0.571$ & $6.12 \pm 0.557$ & $6.12 \pm 0.576$ \\
\hline G.2 (Positive control) & $6.17 \pm 0.528$ & $7.43 \pm 0.522$ & $7.86 \pm 0.521$ & $9.51 \pm 0.523$ & $9.67 \pm 0.515$ \\
\hline G.3 (Standard) & $6.17 \pm 0563$ & $6.71 \pm 0.572$ & $7.18 \pm 0.542$ & $7.31 \pm 0.504$ & $6.65 \pm 0.490$ \\
\hline G.4 (Extract-100 mg/kg) & $6.24 \pm 0.464$ & $7.55 \pm 0.534$ & $7.81 \pm 0.500$ & $8.21 \pm 0.522$ & $7.62 \pm 0.461$ \\
\hline G.5 (Extract- $200 \mathrm{mg} / \mathrm{kg})$ & $6.24 \pm 0.445$ & $7.18 \pm 0.487$ & $7.57 \pm 0.491$ & $7.77 \pm 0.484$ & $7.10 \pm 0.495$ \\
\hline
\end{tabular}

Table 7: Anti-arthritic activity of G. arborea on rat joint diameter (in mm).

\begin{tabular}{|l|c|}
\hline Groups & Arthritic score \\
\hline G.1(Vehicle) & $0.00 \pm 0.00$ \\
\hline G.2 (Positive control) & $3.50 \pm 0.548$ \\
\hline G.3 (Standard) & $1.33 \pm 0.516$ \\
\hline G.4 (Extract- $100 \mathrm{mg} / \mathrm{kg})$ & $2.33 \pm 0.516$ \\
\hline G.5 (Extract- $200 \mathrm{mg} / \mathrm{kg})$ & $1.67 \pm 0.516$ \\
\hline
\end{tabular}

Table 8: Anti-arthritic activity of $G$. arborea on rat Arthritic Index.

\begin{tabular}{|l|c|c|}
\hline Groups & Initial & Final \\
\hline G.1(Vehicle) & $192.83 \pm 6.555$ & $217.17 \pm 6.047$ \\
\hline G.2 (Positive control) & $198.67 \pm 6.218$ & $210.83 \pm 6.555$ \\
\hline G.3 (Standard) & $203.17 \pm 10.998$ & $223.00 \pm 7.772$ \\
\hline G.4 (Extract- $100 \mathrm{mg} / \mathrm{kg})$ & $196.17 \pm 7.935$ & $213.67 \pm 8.756$ \\
\hline G.5 (Extract- $200 \mathrm{mg} / \mathrm{kg})$ & $194.00 \pm 6.870$ & $213.50 \pm 10.232$ \\
\hline
\end{tabular}

Table 9: Effect of G. arborea and indomethacin drug on rat body weight (in gm). 


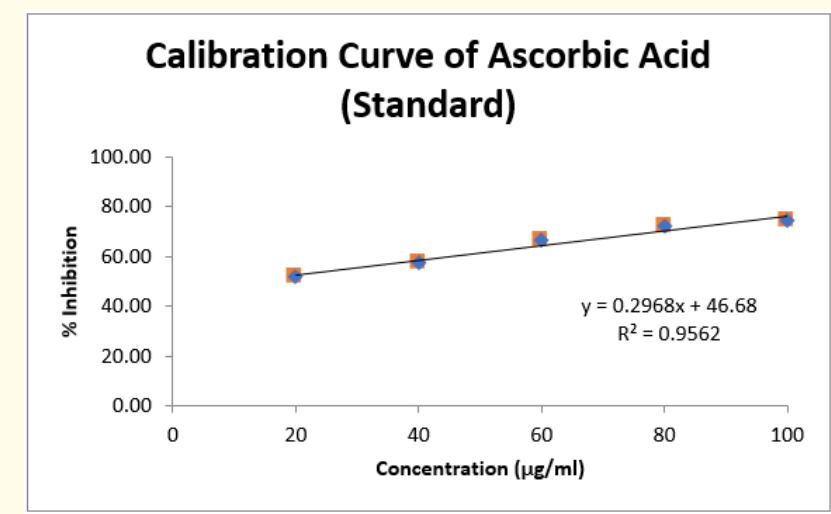

Figure 1: Calibration curve of ascorbic acid.

\section{Conclusion}

The current study established the scientific basis for the ethno medicinal use of Gmelina arborea for arthritis. The study also reveals the medicinal importance of the plant as an anti-inflammatory and free radical scavenger. The plant has the potential to be marketed in the future. The study also documents the use and importance of Gmelina arborea as an ethno medical plant and also suggests a possible alternative solution for arthritis to overcome the limitations and drawbacks of current drugs.

\section{Bibliography}

1. Zawadzka-Bartczak E., et al. "Antioxidative enzyme profiles in fighter pilots". Aerospace Medicine and Human Performance 74 (2003): 654-658.

2. Deshpade V and Jadhav M. "Invitro anti-arthritic activity of Abution indicum". Journal of Pharmaceutical Research 2.4 (2009): 644-645.

3. Feldmann M., et al. "Rheumatoid arthritis". Cell 85.3 (1996): 307-310.

4. Nadkarni KM. “Indian Materia Medica”. Mumbai: Popular Prakashan (2000): 584-585.

5. Kirtikar KR and Basu BD. "Indian Medicinal Plants". Dehradun: International Book Distributors (1999): 1932-1933.

6. Khan IA and Khanum A. "Herbal Therapy for Diabetes". Hyderabad: Ukaaz Publications (2005): 34-35.
7. Rao DV., et al. "Occurrence of luteolin in the leaves of Gmelina arborea Linn”. Current Science 3 (1967): 71-74.

8. Bhattacharjee AK and Das AK. "Phytochemical survey of few mysore Plants". Economic Botany 23 (1969): 274-276.

9. Hosny M., et al. "Twelve acylated iridoid glycosides from Gmelina arborea". Journal of Natural Products 61 (1998): 734-742.

10. Joshi KC., et al. "Extractives from heartwood". Journal of the Indian Chemical Society 48 (1971): 1175-1176.

11. Govindachari TR., et al. "Arboreol, A new lignan from Gmelina arborea". Indian Journal of Chemistry 10 (1972): 1120-1122.

12. Anjaneyulu AS., et al. "The structures of lignans from Gmelina arborea". Tetrahedron 31 (1975): 1277-85.

13. Satyanarayana P., et al. "Arborone and 7-0xo-dihydrogmelinol: Two New Keto-Lignans from Gmelina arborea". Journal of Natural Products 49 (1986): 1061-1064.

14. Shirwaikar A., et al. "Effects of Gmelina arborea Roxb leaves on wound healing in rats". Journal of Natural Remedies 3 (2003): 45-48.

15. Agunua A., et al. "Evaluation of five medicinal plants used in diarrhoea treatment in Nigeria". Journal of Ethnopharmacology 101 (2005): 27-30.

16. Sinha S., et al. "Bark and fruit extracts of Gmelina arborea protect liver cells from oxidative stress". Pharmaceutical Biology 44 (2006): 237-243.

17. Deepak Kumar Jain., et al. "Appraisal of in vitro Antioxidant and in vivo Anti-Inflammatory Activities of Various Extracts from the Fruits of Vitis vinifera L". Scholars Academic Journal of Pharmacy 8.3 (2019): 86-93.

18. Deepak Kumar Jain., et al. "Anti-arthritic activity of tridax procumbens ethanolic extract of leaves". RGUHS Journal of Pharmaceutical Sciences 2.4 (2012): 80-86.

19. Ramya P and Lakshmidevi N. "Studies on anti-oxidant activity of Tinospora cardifolia (Miers)". Journal of American Science 6.10 (2010): 736-743. 
20. Neha P and Dushyant B. "Antioxidant activity of ethanolic extract of Annona squamosa Linn bark". International Journal of Research in Pharmaceutical and Biomedical Sciences 2 (2011): 1692-1697.

21. Veerapur VP., et al. "Ficus racemosa stem bark extract: A potent antioxidant and a probable natural radioprotector". Evidence-Based Complementary and Alternative Medicine 6.3 (2009): 317-324.

22. Badii F and Howell NK. "Effect of antioxidants, citrate, and cryoprotectants on protein denaturation and texture of frozen cod (Gadus morhua)". Journal of Agricultural and Food Chemistry 50 (2002): 2053-2061.

23. Manukumar HM and Umesha S. "Assessment of membrane stabilizing activity from honey. An in-vitro approach". Acta Scientiarum Polonorum, Technologia Alimentaria 14 (2015): 85-90.

24. Chung JI., et al. "Anti-inflammatory effect of low intensity ultrasound (LIUS) on complete Freund's adjuvant-induced arthritis synovium". Osteoarthritis Cartilage 20 (2012): 314-322.

\section{Assets from publication with us}

- Prompt Acknowledgement after receiving the article

- Thorough Double blinded peer review

- Rapid Publication

- Issue of Publication Certificate

- High visibility of your Published work

Website: www.actascientific.com/

Submit Article: www.actascientific.com/submission.php

Email us: editor@actascientific.com

Contact us: +919182824667 